\title{
Perbedaan Hasil Belajar Fisika antara Metode Pembelajaran Kumon dan Metode Pembelajaran Group to Group Exchange pada Siswa Kelas X SMA Negeri 4 Palu
}

\author{
Yuliani, Syamsu dan Muslimin \\ Yuliani12@yahoo.com \\ Program Studi Pendidikan Fisika FKIP Universitas Tadulako \\ Jl. Soekarno Hatta Km. 9 Kampus Bumi Tadulako Tondo Palu - Sulawesi Tengah
}

\begin{abstract}
Penelitian ini bertujuan untuk mengetahui ada tidaknya perbedaan hasil belajar fisika antara siswa yang mengikuti metode pembelajaran kumon dengan metode pembelajaran Group to Group Exchange pada siswa kelas X SMA Negeri 4 Palu. Jenis penelitian ini yaitu kuasi eksperimen dengan menggunakan desain penelitian "posttest-only comparison group design". Populasi penelitian ini adalah seluruh siswa kelas X SMA Negeri 4 Palu, dengan sampel penelitian kelas X MIA 5 berjumlah 31 orang sebagai kelas eksperimen A dan kelas X MIA 6 berjumlah 32 orang sebagai kelas eksperimen B yang diambil dengan menggunakan teknik "nonrandom sampling". Dalam penelitian ini data dikumpulkan melalui tes hasil belajar dalam bentuk pilihan ganda. Data tes akhir kelas eksperimen A dan eksperimen B dianalisis menggunakan analisis statistik, hasil pengujian hipotesis tes akhir diperoleh $t_{\text {hitung }}$ berada di luar penerimaan $H_{0}$ yaitu $t_{\text {hitung }}=2,72$ dan $t_{\text {tabel }}=2,00$ pada taraf nyata $a=0,05$. Dapat disimpulkan bahwa ada perbedaan hasil belajar fisika antara siswa yang mengikuti metode pembelajaran kumon dengan metode pembelajaran Group to Group Exchange pada siswa kelas X SMA Negeri 4 Palu.
\end{abstract}

Kata Kunci: Metode pembelajaran Kumon, Metode pembelajaran Group to Group Exchange, Hasil belajar.

\section{PENDAHULUAN}

Fisika merupakan salah satu ilmu pengetahuan yang memiliki peranan penting dalam kehidupan kita sehari-hari. Pada dasarnya, fisika adalah ilmu dasar, seperti halnya kimia, biologi, astronomi, dan geologi. Teori fisika tidak hanya cukup dibaca, sebab teori fisika tidak sekedar hafalan saja akan tetapi harus dibaca dan dipahami serta dipraktikkan, sehingga siswa mampu menjelaskan permasalahan yang ada. Keluhan tentang kesulitan belajar masih banyak dijumpai, khususnya pada mata pelajaran fisika. Selama ini sebagian besar bahkan hampir setiap orang khususnya para siswa menganggap fisika sebagai pelajaran yang sulit dikuasai, sehingga fisika menjadi mata pelajaran yang kurang disenangi oleh para siswa. Anggapan ini muncul karena penyampaian materi yang sering berbelit-belit dan menggunakan bahasa yang sulit untuk dipahami serta hubungan dengan perhitungan yang rumit dan menggunakan rumus yang banyak. Hal Ini dapat berpengaruh terhadap hasil belajar siswa tersebut.

Hasil belajar siswa pada hakikatnya adalah perubahan tingkah laku yang diperoleh pembelajar setelah mengalami aktivitas belajar [1]. Hasil belajar merupakan bukti sejauh mana pemahaman siswa dalam suatu materi pembelajaran.Salah satu hal yang mempengaruhi tinggi rendahnya hasil belajar siswa yaitu peran aktif guru. Guru harus lebih memperhatikan faktor-faktor yang mempengaruhi hasil belajar sedemikian rupa sehingga dapat terjadi proses belajar yang optimal.

Salah satu usaha yang dapat dilakukan guru untuk meningkatkan hasil belajar siswa terhadap penyelesaian soal adalah dengan menggunakan metode pembelajaran yang melibatkan siswa aktif dalam kegiatan pembelajaran. Beberapa metode pembelajaran yang dianggap mampu untuk meningkatkan hasil belajar siswa adalah metode pembelajaran kumon dan metode pembelajaran Group to Group Exchange (GGE). Namun, kedua metode tersebut memiliki perbedaan yang signifikan dimana metode pembelajaran kumon menuntut siswa untuk dapat mennyelesaikan suatu masalah atau soal secara perseorangan sedangkan metode pembelajaran Group to Group Exchange menuntut siswa untuk dapat menyelesaikan suatu masalah atau soal secara berkelompok. 
Metode pembelajaran kumon adalah metode belajar perseorangan. Level awal untuk setiap siswa pada metode kumon ditentukan secara perseorangan. Siswa mulai dari level yang dapat dikerjakannya sendiri dengan mudah, tanpa kesalahan [2].

Menurut penelitian yang dilakukan oleh Wiharto [3] menunjukkan bahwa metode pembelajaran kumon dapat meningkatkan hasil belajar siswa. Pada metode pembelajaran ini siswa lebih aktif secara nyata mengerjakan tugas-tugas yang diberikan guru, karena dalam pembelajaran dengan metode ini, guru tidak lagi hanya berceramah dan siswa hanya mendengar dan memperhatikan, tetapi siswa harus aktif bekerja mengerjakan soal-soal yang diberikan guru. Ini membuktikan bahwa metode pembelajaran kumon sangat baik diterapkan dalam proses pembelajaran.

Hendrian [4] mengatakan bahwa metode pembelajaran kumon adalah suatu pembelajaran dengan mengkaitkan antara konsep, keterampilan, kerja individu, serta menjaga suasana nyaman menyenangkan. Selain itu, metode Kumon adalah metode belajar yang memberikan program belajar secara perseorangan sesuai dengan kemampuan masing-masing yang memungkinkan siswa menggali potensi dirinya dan mengembangkan kemampuannya secara maksimal. Adapun langkah-langkah metode pembelajaran dengan menggunakan metode kumon yaitu [5]:

a. Memberikan sajian konsep

b. Memberikan latihan

c. Jika ada jawaban yang keliru langsung dikembalikan untuk diperbaiki dan dipariksa lagi

d. Apabila sampai 5 kali masih juga salah guru akan membimbing siswa tersebut.

Menurut silberman [6] metode pembelajaran Group to Group Exchange adalah salah satu metode belajar aktif yang menuntut siswa untuk berfikir tentang apa yang dipelajari, berkesempatan untuk berdiskusi dengan teman, bertanya dan membagi pengetahuan yang diperoleh kepada yang lainnya. Melalui metode belajar aktif tipe GGE, siswa bisa mendengar, melihat, mengajukan pertanyaan tentang materi yang dipelajari, dan mendiskusikan materi dengan siswa lain. Pemberian tugas yang berbeda kepada siswa akan mendorong mereka untuk tidak hanya belajar bersama tetapi juga mengajarkan satu sama lain.

Menurut penelitian yang dilakukan oleh Atma dkk [7] bahwa metode pembelajaran Group to
Group Exchange dapat meningkatkan hasil belajar siswa. Hal ini dikarenakan metode Group to Group Exchange sangat efektif untuk mendorong keaktifan siswa dalam proses pembelajaran serta memberi dampak positif terhadap penyelenggaraan proses pembelajaran.

Silberman [8] mengungkapkan prosedur pembelajaran dengan menggunakan tipe GGE adalah sebagai berikut: (a) Pilihlah topik yang dapat membuat siswa saling bertukar informasi; (b) Bagilah siswa menjadi beberapa kelompok sesuai dengan banyak tugas. Berikan waktu yang cukup kepada tiap kelompok untuk menyiapkan cara mereka menyajikan topik yang ditugaskan kepada mereka; (c) Bila tahap persiapan telah selesai, perintahkan kelompok untuk memilih juru bicara. Undang tiap juru bicara untuk memberikan presentasi kepada kelompok lain; (d) Setelah presentasi singkat, doronglah siswa untuk mengajukan pertanyaan tentang pendapat presenter atau menawarkan pendapat mereka sendiri. Beri kesempatan anggota lain dari kelompok si juru bicara untuk memberi tanggapan; dan (e) Lanjutkan presentasi lain agar tiap kelompok berkesempatan memberikan informasi dan menjawab serta menanggapi pertanyaan dan komentar peserta.

\section{METODE PENELITIAN}

Jenis penelitian ini adalah penelitian kuantitatif dengan rancangan eksperimen kuasi (quasi-experimental design). Penelitian ini dimaksudkan untuk menilai pengaruh suatu tindakan terhadap tingkah laku atau menguji ada tidaknya pengaruh tindakan itu. Tindakan tersebut disebut treatment yang artinya pemberian kondisi yang akan dinilai pengaruhnya.

Adapun desain penelitian yang digunakan yaitu "Posttest-Only Comparison Group Design" [9]. Desain penelitian yang digunakan dapat dilukiskan seperti pada Tabel 1.

\begin{tabular}{ccc} 
Tabel 1. Posttest-Only Comparison Group Design \\
\hline Kelompok & Perlakuan & Post Test \\
\hline A (KE) & $X_{A}$ & 0 \\
B (KE) & $X_{B}$ & 0 \\
\hline
\end{tabular}

Keterangan:

$\mathrm{X}_{\mathrm{A}}$ : Perlakuan untuk kelas eksperimen dengan menerapkan metode Pembelajaran kumon 
$\mathrm{X}_{\mathrm{B}}$ : Perlakuan untuk kelas eksperimen dengan menerapkan metode Pembelajaran Group to Group Exchange.

O : Tes Akhir

Penelitian dilakukan dikelas $X$ jurusan Matematika dan Ilmu Alam (MIA) SMA Negeri 4 Palu. Penelitian dilaksanakan pada bulan November-Desember 2014. Populasi dalam penelitian ini adalah seluruh siswa kelas XI IPA SMA Negeri 4 Palu tahun pelajaran 2014/2015 yang terdiri dari 7 kelas. Sampel dalam penelitian ini adalah kelas X MIA 5 dan MIA 6 . Teknik pengumpulan sampel yang digunakan adalah nonrandom sampling yaitu teknik penentuan sampel dengan memilih kelas-kelas yang diperkirakan sama keadaan/kondisinya antara lain kedua kelas memiliki jumlah siswa yang kurang lebih sama dan diajar oleh guru fisika yang sama.

\section{HASIL DAN PEMBAHASAN}

Berdasarkan hasil analisis validitas item, dari 35 nomor soal yang diujikan, diketahui 21 diantaranya diterima, artinya layak untuk diujikan pada siswa. Sedangkan 4 nomor soal lainnya diputuskan untuk direvisi, artinya soal tersebut dapat diujikan dengan catatan soal telah diperbaiki baik dari segi isi maupun konstruksinya. Peneliti merevisi 4 nomor soal yang perlu direvisi, sehingga total soal yang diujikan untuk tes akhir di kelas eksperimen $A$ maupun kelas eksperimen B berjumlah 25 soal.

Data yang digunakan untuk menguji normalitas data meliputi hasil posttest hasil belajar baik pada kelas eksperimen A maupun kelas eksperimen B. Pengujian data normalitas data penelitian ini peneliti menggunakan uji Chi-kuadrat dengan kriteria penerimaan $\chi_{\text {hitung }}^{2}<\chi^{2}$ tabel, taraf signifikan $\alpha=0,05$, dan derajat kebebasan $\mathrm{dk}=\mathrm{k}-3$. Hasil uji normalitas posttest dari kelas eksperimen A maupun kelas eksperimen $\mathrm{B}$ dapat dilihat pada Tabel 2.

Tabel 2. Hasil Uji Normalitas Posttest Kelas Eksperimen A dan Kelas Eksperimen B

\begin{tabular}{ccc}
\hline \multirow{2}{*}{ Uraian } & \multicolumn{2}{c}{ Posttest } \\
\cline { 2 - 3 } & Eksperimen A & Eksperimen B \\
\hline Sampel & 31 & 32 \\
\hline$\chi^{2}$ hitung & 2,48 & 1,75 \\
\hline$\chi_{\text {tabel }}^{2}$ & \multicolumn{3}{c}{7,81} \\
\hline Ket & \multicolumn{3}{c}{ Normal } \\
\hline
\end{tabular}

Berdasarkan uji normalitas pada Tabel 2 dengan kriteria penerimaan $\chi^{2}$ hitung $<\chi^{2}$ tabel, dimana untuk posttest baik kelas eksperimen $\mathrm{A}$ maupun kelas eksperimen $B$ nilai $\chi^{2}$ hitung lebih kecil daripada nilai $\chi^{2}$ tabel. Artinya, baik kelas eksperimen A maupun kelas eksperimen B berasal dari populasi yang terdistribusi normal.

Pengujian data homogenitas menggunakan uji-F dengan kriteria jika $F_{\text {hitung }}<F_{\text {tabel }}$ maka sampel dinyatakan homogen atau sebaliknya. Hasil uji homogenitas dari kelas eksperimen A dan kelas eksperimen $B$ dapat dilihat pada Tabel 3.

Tabel 3. Hasil Uji Homogenitas Posttest

\begin{tabular}{ccc}
\hline Uraian & Posttest & Ket \\
\hline$F_{\text {hitung }}$ & 1,47 & Homogen \\
$F_{\text {tabel }}$ & 1,82 & \\
\hline
\end{tabular}

Berdasarkan Tabel 3, hasil uji homogenitas menunjukkan nilai $\mathrm{F}_{\text {hitung }}<\mathrm{F}_{\text {tabel }}$ pada hasil posttest. Hal ini berarti kelas eksperimen A dan kelas eksperimen B berasal dari populasi yang homogen (memiliki varians yang sama).

Pengujian hipotesis ini menggunakan statistik parametrik uji-t (uji dua pihak). Kriteria penerimaan $\mathrm{H}_{0}$ jika $t_{\text {hitung }}<t_{\text {tabel }}$ pada taraf signifikan $\alpha=0,05$. Data hasil pengujian statistik posttest dapat dilihat pada Tabel 4

Tabel 4. Uji Hipotesis posttest

\begin{tabular}{cccccc}
\hline No & Kelas & $\overline{\mathbf{X}}$ & $\mathbf{t}_{\text {hitung }}$ & $\begin{array}{c}\mathbf{t}_{\text {tabel }} \boldsymbol{\alpha = \mathbf { 0 , 0 5 } )} \\
\text { Keputusan }\end{array}$ \\
\hline 1 & Eksperimen A & 16,55 & 2,72 & 2,00 & $\begin{array}{c}\mathbf{H}_{\mathbf{1}} \\
\text { diterima }\end{array}$ \\
\hline & Eksperimen B & 14,97 & & & diterima \\
\hline
\end{tabular}

Data pada Tabel 4 menunjukkan $t_{\text {hitung }}>t_{\text {tabel }}$ atau 2,72>2,00. Hal ini berarti, nilai thitung berada pada daerah penerimaan $\mathrm{H}_{1}$. Dengan demikian $\mathrm{H}_{0}$ ditolak dan $\mathrm{H}_{1}$ diterima. Hal ini berarti terdapat perbedaan hasil belajar fisika antara siswa yang mengikuti metode pembelajaran kumon (kelas eksperimen A) dengan siswa yang mengikuti metode pembelajaran Group to Group Exchange (kelas eksperimen B).

Penelitian ini bertujuan untuk mengetahui perbedaan hasil belajar fisika antara kelas yang mengikuti metode pembelajaran kumon dengan kelas yang mengikuti metode pembelajaran Group to Group Exchange. Metode pembelajaran kumon merupakan metode pembelajaran aktif yang memberikan program belajar secara perseorangan sesuai dengan kemampuan masing-masing, yang memungkinkan anak menggali potensi dirinya dan mengembangkan kemampuannya secara maksimal. Sedangkan metode pembelajaran Group to Group Exchange merupakan metode belajar aktif yang menuntut siswa untuk berfikir tentang apa yang dipelajari, berkesempatan untuk berdiskusi dengan teman, bertanya dan 
membagi pengetahuan yang diperoleh kepada yang lainnya.

Untuk mengetahui hasil belajar dari masingmasing kelas yang dijadikan sampel penelitian digunakan instrumen dalam bentuk tes hasil belajar. Selanjutnya, dengan tujuan untuk mengetahui validitas, tingkat kesukaran, daya pembeda, dan reliabilitas tes maka instrumen diuji cobakan pada siswa kelas XI IPA 2 SMA Negeri 5 Palu sebanyak 35 butir soal.

Banyaknya item yang diterima didasarkan pada analisis koefisien korelasi biserial point, indeks kesukaran, dan daya pembeda soal (lampiran 4 dan 5). Selain ketiga kriteria di atas, juga digunakan kriteria penerimaan tiap item $(\sigma)$ yang bergantung pada jumlah item yang diuji cobakan yaitu $\sigma=0,17$. Nilai tersebut dibandingkan dengan harga koefisien biserial point $\left(r_{p b i}\right)$ jika suatu item memiliki harga koefisien biserial point sama dengan atau di atas nilai tersebut $\left(r_{\mathrm{pbi}} \geq 0,17\right)$ maka item tersebut diterima dan dapat digunakan sebagai alat ukur. Terdapat satu item yang harga $r_{p b i} \geq$ 0,17 namun tidak diterima karena memiliki indeks kesukaran dan daya pembeda pada kategori mudah dan jelek, dari 24 siswa yang mengikuti tes uji coba hanya 5 orang siswa yang tidak dapat menjawab dengan benar. Untuk itu, peneliti berkesimpulan item tersebut tidak diterima.

Untuk mengetahui perbedaan hasil belajar fisika antara kelas eksperimen A dengan kelas eksperimen B dilakukan uji hipotesis menggunakan uji t dua variabel bebas ( 2 pihak) dengan syarat kedua sampel terdistribusi normal dan berasal dari populasi yang homogen. Pada pengujian hipotesis dengan $a=$ 0,05 diperoleh $t_{\text {hitung }}>t_{\text {tabel }}$. Dengan nilai $t_{\text {hitung }}$ $=2,72$ dan $t_{\text {tabel }}=2,00$ pada $a=0,05$. Selain itu, dapat pula dilihat pada nilai rata-rata posttest siswa kelompok eksperimen $A$ dan eksperimen $B$, masing-masing $\bar{X}_{1}=16,55$ dengan standar deviasi $=2,52$ dan $\bar{X}_{2}=14,97$ dengan standar deviasi $=2,08$. Dengan kata lain, terdapat perbedaan hasil belajar fisika antara siswa yang mengikuti metode pembelajaran kumon (kelas eksperimen A) dengan siswa yang mengikuti metode pembelajaran Group to Group Exchange (kelas eksperimen B).

Perbedaan hasil belajar fisika oleh siswa pada kelas eksperimen A dan kelas eksperimen B dipengaruhi oleh peran metode pembelajaran yang diterapkan dimasing-masing kelas. Metode pembelajaran kumon yang diterapkan di kelas eksperimen A merupakan metode belajar yang memberikan program belajar secara perseorangan sesuai dengan kemampuan masing-masing. Hal tersebut telah dibuktikan pada penelitian yang dilakukan oleh Wiharto yang berjudul "Efekifitas Pembelajaran Matematika Dengan Menggunakan Metode Kumon Terhadap Prestasi Belajar Matematika Pokok Bahasan Logika Matematika Pada Siswa SMA". Hasil penelitiannya menunjukkan bahwa dengan menggunakan metode kumon, siswa menjadi terbiasa dalam mememecahkan masalah secara terampil dan dapat memberikan ruang kepada siswa untuk belajar sesuai dengan gaya mereka. Sehingga siswa terlihat lebih santai dan interaktif dalam proses belajar mengajar.

Pada proses pembelajaran dengan menggunakan metode kumon, mula-mula guru menyajikan konsep dan siswa memperhatikan penyajian tersebut. Selanjutnya, siswa diberikan lembar kerja berupa latihan soal untuk dikerjakan secara mandiri. Setelah siswa selesai mengerjakan, lembar kerja diserahkan kepada guru untuk diperiksa dan langsung diberi nilai. Bila ada bagian yang masih salah, siswa diminta untuk membetulkan bagian tersebut hingga semua lembar kerjanya memperoleh nilai 100 . Jika siswa sampai mengulang 5 kali, maka guru melakukan pendekatan kepada siswa dan menanyakan tentang kesulitan-kesulitan yang dihadapi.

Berbeda dengan metode pembelajaran kumon, metode pembelajaran Group to Group Exchange (GGE) di kelas eksperimen B adalah salah satu metode belajar yang menuntut siswa untuk berfikir tentang apa yang dipelajari, berkesempatan untuk berdiskusi dengan teman, bertanya dan membagi pengetahuan yang diperoleh kepada yang lainnya. Dalam metode GGE masing-masing kelompok diberi tugas untuk membahas satu topik materi, siswa dituntut untuk menguasai materi karena setelah diskusi kelompok berakhir, siswa akan bertindak sebagai guru bagi siswa yang lain dengan mempresentasikan hasil dari diskusinya.

Adapun proses pembelajaran metode Group to Group Exchange yatu mula-mula guru memilih sebuah topik yang mencakup ide, kejadian, posisi, konsep, pendekatan untuk ditugaskan. Sebelum memulai pembelajaran, hendaknya ditentukan terlebih dahulu topik atau materi yang dapat membuat siswa saling bertukar informasi. Kemudian menentukan jumlah topik yang akan ditugaskan kepada siswa. Selanjutnya membagi siswa menjadi beberapa kelompok sesuai jumlah tugas/topik dan memilih seorang juru bicara pada masing- 
masing kelompok untuk menyampaikan hasil diskusi kepada kelompok lain. Setelah presentasi singkat, siswa bertanya atau memberikan tanggapan kepada kelompok penyaji. Kemudian melanjutkan sisa presentasi agar setiap kelompok memberikan informasi dan merespon pertanyaan juga komentar penyaji.

Berdasarkan penelitian yang dilakukan oleh Atma yang berjudul "Penerapan Metode Belajar Aktif Tipe Group To Group Exchange Untuk Meningkatkan Hasil Belajar Matematika Siswa Kelas X IPS 1 MAN 2 Model Pekanbaru" membuktikan bahwa metode pembelajaran Group to Group Exchange dapat meningkatkan hasil belajar siswa. Hasil penelitiannya menyatakan bahwa metode Group to Group Exchange sangat efektif untuk mendorong keaktifan siswa dalam proses pembelajaran serta memberi dampak positif terhadap penyelenggaraan proses pembelajaran.

Akan tetapi, pada pelaksanaan dilapangan diperoleh nilai rata-rata hasil belajar siswa lebih rendah menggunakan metode Group to Group Exchange yaitu 14,97 dibandingkan dengan nilai rata-rata hasil belajar siswa menggunakan metode kumon yaitu 16,55 . Hal tersebut dapat dipengaruhi oleh beberapa faktor diantaranya sebagian besar siswa kelas eksperimen B merasa bosan untuk melakukan kerja kelompok dimana metode Group to Group Exchange itu sendiri merupakan metode belajar secara berkelompok. Sehingga ada beberapa kendala yang terjadi diantaranya ketua kelompok sulit membuat dan mengadakan pembagian kerja, ada beberapa anggota kelompok yang kurang terlibat dalam pembelajaran sehingga kurang mengaktifkan diskusi kelompok, sebagian besar anggota kelompok tidak mematuhi tugas yang diberikan oleh ketua kelompok, dan sering tidak terkendali sehingga menyimpang dari rencana yang telah ditentukan. Selain itu, faktor lain yang mempengaruhi adalah waktu pelaksanaan proses kegiatan belajar mengajar kelas eksperimen $\mathrm{B}$ dilaksanakan pada siang hari yaitu pada jam 11.15 WITA sampai jam 14.00 WITA. Sedangkan waktu pelaksanaan proses kegiatan belajar mengajar kelas eksperimen A dilaksanakan pada pagi hari. Hal ini memberikan dampak pada hasil belajar yang diperoleh lebih rendah.

Namun demikian, ada beberapa kendala yang perlu diperhatikan pula pada proses pembelajaran metode kumon diantaranya dibutuhkan waktu yang lebih banyak karena setiap siswa memiliki kemampuan belajar yang berbeda-beda serta guru harus bertindak selaku pemandu yang selalu mengamati satu per satu siswa dengan baik dan memberikan lembar kerja serta pendekatan yang sesuai dengan kemampuan setiap siswa agar terbentuk kemampuan belajar.

\section{IV.KESIMPULAN}

Berdasarkan hasil penelitian dan analisa data penelitian, maka dapat ditarik kesimpulan bahwa ada perbedaan hasil belajar fisika antara siswa yang mengikuti metode pembelajaran Kumon dan metode pembelajaran Group to Group Exchange. Hal ini dibuktikan dengan hasil $u j i$ hipotesis dimana nilai $t_{\text {hitung }}>t_{\text {tabel }}$. dengan nilai $t_{\text {hitung }}=2,72$ dan $t_{\text {tabel }}=2,00$ pada $a=0,05$ dan $t_{\text {hitung }}=2,72$ dan $t_{\text {tabel }}=2,66$ pada $\mathrm{a}=0,01$. Berdasarkan pada ketentuan jika $t_{\text {hitung }}>t_{\text {tabel }}$ maka $\mathrm{H}_{0}$ ditolak dan $\mathrm{H}_{1}$ diterima. Hal ini berarti bahwa terdapat perbedaan antara penggunaan kedua metode pembelajaran ini.

\section{DAFTAR PUSTAKA}

[1] Catharina, 2005. Belajar dan Pembelajaran. Jakarta: Asdi Mahasatya.

[2] Kumon, Toru. 2006. Metode Kumon. Jakarta: PT. Kie Indonesia.

[3] Wiharto, Priyo. 2011. Efekifitas Pembelajaran Matematika Dengan Menggunakan Metode Kumon Terhadap Prestasi Belajar Matematika Pokok Bahasan Logika Matematika. Semarang : IKIP PGRI.

[4] Hendrian. Metode Pembelajaran Kumon, (online), (Http://id. Kumon Global. Com, diakses 12 Januari 2012).

[5] Junaidi \& Yuni Asrina. 2012. Pengaruh Metode Pembelajaran Kumon Terhadap Peningkatan Hasil Belajar Matematika Siswa Di Kelas VIII MTSN Sigli Pada Materi Limas. Journal SAINS Riset Volume 3No.1.

[6] Silberman, M. 2006. Active Learning 101 Cara Belajar Siswa Aktif. Bandung: Nusamedia

[7] Murni, Atma, dkk. 2010. Penerapan Metode Belajar Aktif Tipe Group To Group Exchange Untuk Meningkatkan Hasil Belajar Matematika Siswa Kelas $X$ IPS 1 MAN 2 Model Pekanbaru. Jurnal Penelitian Pendidikan Vol.11-No.2.

[8] Silberman, M. 2006. Active Learning 101 Cara Belajar Siswa Aktif. Bandung: Nusamedia.

[9] Syaodiah S. Nana. (2011). Metode Penelitian Pendidikan. Bandung: PT. Remaja Rosdakarya. 